\title{
RAD18 wt Allele
}

National Cancer Institute

\section{Source}

National Cancer Institute. RAD18 wt Allele. NCI Thesaurus. Code C106245.

Human RAD18 wild-type allele is located within 3p25-p24 and is approximately $188 \mathrm{~kb}$ in length. This allele, which encodes E3 ubiquitin-protein ligase RAD18 protein, is involved in both repair of UV-damaged DNA and protein ubiquitination. 